\title{
The Catholic Church in need of de-clericalisation and moral doctrinal agency: Towards an ethically accountable hierarchical leadership
}

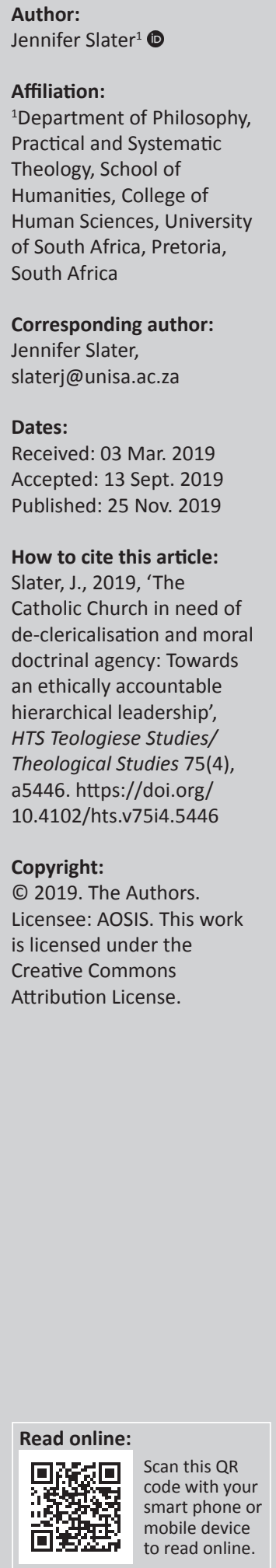

Author:

Affiliation

${ }^{1}$ Department of Philosophy,

Practical and Systematic

Theology, School of

Human Sciences, University

of South Africa, Pretoria

Jennifer Slater,

Dates:

Received: 03 Mar. 2019

Accepted: 13 Sept. 2019

is article:

Catholic Church in need of

de-clericalisation and mora

a5446. https://doi.org/

Copyright

Licensee: AOSIS. This work

is licensed under the

Creative Commons

mobile device

to read onlin
Under normal circumstances the church would function as an agent of change and transformation, but this article focuses on the church herself that needs radical change if she is to remain relevant in mission and ministry in this current era. Clericalism and the centralisation of hierarchical control can be identified as the root causes of institutional pathology and weakening collegiality. To address clericalism may require the adjustment of seminary training, as in the current system seminarians are nurtured in a sense of separateness, promoting maleego and feed gender exclusivity and doctrinal self-righteousness. While the seminary was once an instrument of reform in the Catholic Church, established to counter problems such as clerical concubinage and illiteracy, but now it is no longer suitable as it has become the forum that breeds other problems. Priority attention should be paid to purge the church of rampant clericalism, discriminatory scapegoating of gay persons, marginalisation of free thinkers, exclusion of women priests, the perceived moral laxity of family life issues and reception of communion by divorced Catholics without the benefits of annulment. Discrediting the personal authority of the pope is hardly an enlightened option. What ought to be transformed is the centralisation of control and allowing increased localised dominion whereby crises such as sexual abuse scandals could be addressed and solved more speedily and liberally, and limit the need to go to the top for solutions. To wait for centralised, hierarchal structures to deal with urgent issues is not desirable, as speedy accountability is needed to address issues that hurt the church in its entirety.

Keywords: Clericalism; De-clericalism; Sacerdotal clericalism; Ultramontanism; Apostolic Succession; Ontological change; Seminary formation; Indelible mark; Servus Servorum Dei; Clerical abuse; Hierarchical clerical structure; Excommunication.

\section{Introduction}

In recent years, the Roman Catholic Church has come under much criticism and scrutiny concerning the scourge of sexual abuse of minors by clerics. In February 2019, Pope Francis summoned approximately 200 bishops from around the world to give urgent attention to this disturbing matter. On 08 March 2019, Abraham (2019), from the Mail and Guardian, reported the following:

The pope's belief in the link between clericalism and the abuse scandal has long been known. Clericalism, he asserts, is an illness or ailment in the church; it promotes the idea that 'the church' means 'priests and bishops', and ignores the contribution of lay people. (n.p)

Clericalism has often been linked to abuses in the church such as child sexual abuse, religious entitlement, superiority and unethical hierarchical claims and privilege. There is, however, a difference between the office of the priesthood and clericalism, although the interconnection is deep-seated and inextricable. Clericalism is directly linked to seminarian formation towards the office of priesthood whereby candidates precipitously perceive themselves as distinct from the 'faithful' or the 'laity' in whose pastoral service they are meant to be. Pope Francis while addressing the 2018 Synod for Young People suggested that clericalism interprets vocation as an exercise of power rather than providing service. He called it perversion, which is at the root of many evils in the church. Hence, it is the aim of this article to address this distortion, its causes and consequences. An assessment of priestly preparation is deemed essential to combat excessive clericalism and widespread moral problems. Wholesome preparation generally results in altruism, self-abnegation and inclusiveness, and authentic priesthood does not reduce the faithful (laity), women, gay persons and divorced persons to submissive bystanders, whereas 
clericalism is culpable to many of these issues. It is the suggested view of this article that the Roman Catholic Church is indeed in need of de-clericalism and moral doctrinal agency towards ethical accountability of unaffected priestly leadership as was stipulated by Pope Francis in Apostolic Exhortation Gaudete Et Exsultate (2018a:10-13) in his call to holiness. All people ordained or not ordained need acknowledgement with respect to functional participation in the Church. While clericalism drives a rift between the clergy and the laity, it is true that some laity is more clerical and promotes clericalism further than the clergy themselves. Pope Francis is a powerful critic of clericalism regardless of whether it is fostered by both the faithful and the clergy. In August 2018, Pope Francis (2018b) in his Letter to the People of God wrote the following:

Clericalism, whether fostered by priests themselves or by lay persons, leads to an excision in the ecclesial body that supports and helps to perpetuate many of the evils that we are condemning today. To say 'no' to abuse is to say an emphatic 'no' to all forms of clericalism. (p. 1)

This article wishes to address differences between priesthood and clericalism, and proposes ways how the church needs to act as an agent of change so as to restore priesthood according to the teachings of the Gospel and create healthier laypersonclergy relations in the light of the teachings of the Second Vatican Council. This article separates priesthood from clericalism and the present agency in the context of a positive vision of the Church whereby the laity and clergy observe one another with mutual respect and function as partners in the mission of the church to the world, employing relevant tasks related to their own special vocations.

\section{Clericalism versus priesthood}

What is clericalism? Neuhaus (2008:60) describes clericalism as the shadow side of the glory of the Catholic priesthood: It is a form of elitism, clerical elitism. Before this, in 1993, Russel Shaw (a prolific writer on clericalism) wrote in his book, To Hunt, To Shoot, To Entertain: Clericalism and Catholic Laity, that clericalism goes back to the origins of the church. By clericalism, Shaw (2008) reiterates as follows:

I mean an elitist mind-set, together with structures and patterns of behaviour corresponding to it, which takes it for granted that clerics, in the Catholic context, mainly bishops and priests, are intrinsically superior to the other members of the Church and deserve automatic deference.(p. 16)

Passivity and dependence of the laity are lamentable results against the teachings of the Second Vatican Council. By no means is clericalism confined to clerics themselves. The clericalist mind-set is widely shared and emboldened by Catholic lay people (Shaw 2008:16).

'Clericalism', says Shaw (1993:13), 'is not ultramontanism,' not a failure to consult the laity, it is something deeper and

1.Ultramontanism - "over-the-mountain-ism" - was a theological, cultural and political movement within the Roman Catholic Church that promoted the powe and authority of the Pope. The movement was encouraged by Pope Pius IX, and more pervasive'. Jesus, he claims, was a victim of a clericalist mentality of his time. Since Jesus challenged the authority of the religious and social elite of a theocratic society, he subsequently paid with his life. This does not imply that clericalism in the Catholic Church is literally responsible for anybody's death, but it is a cause of many victims, psychologically, emotionally as well as spiritually. The clerical mind-sets, be it from clericalised laity or clericalised clergy, distort and disrupt Christian lives and members of the church, both the clergy and laity alike. This mind-set also weakens the Church in the service of mission and evangelisation according to the teachings of the Gospel (Shaw 1993:14). In 2018, Shaw reiterated the following in the Clericalist Syndrome2: 'Clericalism did not cause sex abuse, nor did sex abuse cause clericalism. But the connection is very real'. Shaw (2008:15) quotes from Nothing to hide: Secrecy, communication, and communion in the Catholic Church that 'sex abuse in a clericalist social setting naturally takes on a clericalist coloration, making it difficult to keep the two things separate and distinct'.

Pope Francis, who is extremely outspoken against clericalism, has taken up the same Shaw baton and regards clericalism as a sin committed by both the clergy and the laity. In the case of the clergy (ordained deacons, priests and bishops), clericalism is when they demand to be treated as superior to the laity; and for laity, when they render themselves to the attitude that the priest must do everything and reneged on the responsibilities that are theirs by virtue of their baptism. On 20 August 2018, in a letter ${ }^{3}$ that he wrote to the People of God, Pope Francis (2018b) defines clericalism as a 'false or sycophantic respect and esteem for clergy'. It lends to the persons of the priests, in view of their clerical office, an excessive deference and acquiescence. Addressing the Bishops at St Peter's Square on 05 November 2014, the Pope did not spare his words concerning clericalism. He categorised clericalism as a negative pathway to sterile authoritarian ecclesiastical careerism, privilege, entitlement and power. Glatz (2014) stated in his speech, 'Bishops must be servants, not vain careerists after power, honour':

$[W]$ hen I meet a clericalist, I suddenly become anti-clerical. Clericalism should not have anything to do with Christianity. St. Paul, who was the first to speak to the Gentiles, the pagans, to believers in other religions, was the first to teach us that: It's sad when you see a man who seeks this office and who does so much to get there and when he makes it, he doesn't serve, but struts like a peacock, living only for his own vanity. (n.p.)

In clericalist culture, 'the clergy often stand above and aloof to their flocks, to a distance the faithful can respond in a childish spirit of obedience and false reverence' (Pope Francis 2018a). In his homily on 13 December 2016, Pope Francis

culminated in the definitions of papal primacy and infallibility of the First Vatican Council.

2.The Catholic Thing is a forum for intelligent Catholic commentary. Opinions expressed by writers are solely their own.

3.The Pope writes letters regularly to the People of God that are read in churches around the globe. This Letter of His Holiness Pope Francis to the People of God was read on 20 August 2018. 
(2016) said: 'Clericalism is a really awful thing; it is a new edition of this ancient evil of the religious "authorities" lording it over others'. But 'the victim is the same: the poor and humble people, who await the Lord' (Casa Santa Marta). When he addressed young Italians, the Pope says that clericalism happens 'when the cleric doesn't have time to listen to those who are suffering, the poor, the sick, the imprisoned, it is a perversion of the Church' (Meeting with young Italians, 11 August 2018, Dialogue of The Holy Father With the Young).

Clericalism is, hence, sharply associated with the ordained clergy, which present themselves as a dominant elite of the church, are predominantly male in gender, and in the process they render to be faithful subservient. This, wrote Shaw (1993:14) almost prophetically, deepened the confusion concerning the identity and roles of clergy and laity in the church as well as the crisis regarding priestly and religious life vocations. He maintains that it is also a factor of inappropriate political activism of some clerics that plays a role in the controversy over women's ordination. ${ }^{4} \mathrm{He}$ was of opinion that it discouraged the faithful from cultivating a spirituality that rose above the level of fervour and intensity, counter to the call to holiness by the Second Vatican Council.

Clericalism had sadly been intensely connected with sexual abuse scandals that became public in 2002 and whereby the Catholic Church has taken a grave knock concerning the integrity of the priesthood. The Church was forced, under duress, to examine the whole issue of clericalism and sexual abuse as a combined evil that has damaged the authenticity of the priesthood. In the light of sexual scandals, Michael Kelly SJ described clericalism as a culture of self-interest, which promotes and sustains the presumption of superiority among clergy and their practice of protective secrecy. 'It is something that priests share with all would-be elites, such as professional associations in law and medicine, bureaucrats and the military' (Kelly 2014:434). It is described as an aberration that engenders disdain and disrespect for others, especially for those who are not clerics (not ordained). Real clericalism, in the words of Trigilio (2015:434), is apparent when a deacon, priest or bishop has an attitude of superiority over his flock in that he believes he is 'better' than they are, whether it is spiritually, intellectually or otherwise. Clericalism patronises and denigrates the faithful. It seeks to be treated with privilege, rather than seeking to be of service. Genuine priesthood clamours the opposite, to be in truthful service of the People of God.

\section{Clericalism has a history}

As indicated, clericalism is not a new phenomenon and can be traced even to the post-Apostolic church. Primitive Christian clericalism was already evident in the Early Jesus Movement when the powers and authorities were concentrated in the hands of an elite few. It appeared as well established by the end of the Apostolic age at the closing of the 1st century CE. All the baptised of the early Christian 4.The exclusion of women from ordination in the Catholic Church is perceived by this article as one of the factors in need of agency. communities realised their calling to discipleship, mutual service and bearing witness to the Resurrected Christ, nevertheless, their gifts and ministries gradually became subject to scrutiny and moderation by community overseers and leaders. By Paul's time, the leadership of the Early Jesus Movement was already an established and functional structure. By $110 \mathrm{CE}$, Ignatius of Antioch provided a very clear description of the titles and functions of community leaders in his community as was described in the non-Pauline epistles: 1Timothy and Colossians (Bergenke 2006:1).

The structure of early Christian worship took its form from the Jewish synagogue worship and became the OikosEkklesia, the Christian house church. It was situated in a community setting, which comprised some forms of Jewish synagogal worship, followed by communal meal, wherein the Memorial of the Lord's Supper was observed. The leadership and management of the house-church comprised episkopos (overseers) who in turn was supported by diakonoi (deacon). The evangelical task was that of apostolos (itinerant presbyter) that consisted in doing the rounds of local communities to encourage and confirm their faith and strengthen the bonds of unity. The apostolos was considered genuine successors of the Twelve Apostles. In the Epistle of Ignatius to the Smyrnaeans, Chapter 8, entitled 'Let nothing be done without the bishop', it reads as follows:

See that you all follow the bishop, even as Jesus Christ does the Father, and the presbytery as you would the apostles; and reverence the deacons, as being the institution of God. Let no man do anything connected with the Church without the bishop. Let that be deemed a proper Eucharist, which is [administered] either by the bishop, or by one to whom he has entrusted it. Wherever the bishop shall appear, there let the multitude [of the people] also be; even as, wherever Jesus Christ is, there is the Catholic Church. It is not lawful without the bishop either to baptize or to celebrate a love-feast; but whatsoever he shall approve of, that is also pleasing to God, so that everything that is done may be secure and valid. (para. 2)

The Didache Chapter 11, deals with teachers, apostles and prophets, according to the decree of the Gospel, whereas Didahe Chapter $15^{5}$ reproofs the hierarchy:

Appoint for yourselves therefore bishops and deacons worthy of the Lord, men who are meek and not lovers of money, and true and approved; for unto you they also perform the service of the prophets and teachers. Therefore despise them not; for they are your honourable men along with the prophets and teachers...(para. 1).

By the early 2nd century, the age of the wandering charismatic apostles came to an end. The episkopos had begun to consolidate both charisma and functions of apostles, the forerunners of bishops and the 'Apostolic Succession'. ${ }^{6}$ While assuming the role of an apostle, they also exerted authority and who would preside over the house Church Eucharistic

5.Didache Chapter 12 deals with Bishops, Deacons and Christian reproof.

6.Apostolic succession is the doctrine taught by the Roman Catholic Church that adheres to the uninterrupted transmission of spiritual authority from the Apostles through successive popes and bishops, but denied by most Protestants. This is deemed necessary for the valid administration of sacraments and the transmission of orders. 
celebration as well as the other rites of initiation. It became an acceptable practice that the Eucharist was celebrated by either the bishop or someone he authorises (the presbyter). 'Where the bishop is present, there let the congregation gather, just as where Jesus Christ is, there is the Catholic Church' (see Smyrnaeans Chapter 8 and Chapter 9):

Let nothing be done without the bishop: Let that be deemed a proper Eucharist, which is [administered] either by the bishop, or by one to whom he has entrusted it. (Ch. 8)

Honour your bishop...It is well to reverence both God and the bishop. He who honours the bishop has been honoured by God... (Ch. 9)

The role of the bishop began to take on the attributes of the sacred world, and according to Scholastic theology the effect of 'ordination' to priestly/episcopal office was described as an 'ontological' transformation of the one ordained. This sacred status was recognised by Constantine's Imperial law applicable to bishops, deacons and presbyters. The culture of clericalism was validated and consolidated in the 11th century by the Canonical and disciplinary reforms of Gregory VII, ${ }^{7}$ elevated to the position of the clerical state, guaranteed protection under church laws and enjoyed superiority over civil laws. Pope Gregory Vll established and consolidated a monarchical papacy, which held absolute power (Bergenke 2006:1).

\section{Priesthood and the concept of Ontological transformation}

The theology of ontological transformation is particularly attached to three of the seven sacraments in the Catholic Church, namely baptism, confirmation and ordination. Bennett (2014) relates that in the sacramental theology of Roman Catholicism, the priest is an icon of Christ and ministerial ordination is an ontological transformation, that is, a change in a person's very being. Therefore, it is necessary that the priest be able to represent (re-present) Christ and to be ontologically changed so as to act in the person of Christ. (persona Christi, p. 104)

This doctrine not only excluded women from ordination but also presented the male sex of Christ as an unalterable substance of the sacrament. It is, therefore, necessary that the priest be able to represent Christ's maleness. The significant point of contestation in the words of Bennett (2014) is this:

[T] he female body's inability to resemble Christ's male body is indicative of a woman's inability to represent Christ and, therefore, her inability to receive the character of ordination and so also her inability to act in persona Christi. (p. 105)

Sacramental theology refers to it as a change that takes place within the nature of the 'being' or 'existence' of a person. It is a term that received prominence during the scholastic teachings of Saint Thomas Aquinas (1224-1274). However,

7.Pope Gregory Vill was Pope from 1073 till his death in 1085. He was known as the great reforming pope and was steering developments in the relationship between the emperor and the papacy. the ontological argument was framed by Anselm of Bec (1033) in his Proslogion and it dwelt on the existence of God and everything that we believe about the Divine Nature (Richardson \& Bowden 2002:415). Thomas Aquinas regarded it as an argument of different kind, and did not include it in the five proofs of the existence of God in his Summa Theologiae, because he was of the opinion that God's existence is self-evident, and couldn't be deduced from claims about the concept of God (Richardson \& Bowden 2002:417). The ontological argument became a subject of discussion in every subsequent century among philosophers such as Kant, Hume, Descartes and Heidegger right up to the present time.

Theologically speaking, the term 'ontological change' is appropriated by all the sacraments, but especially for baptism, confirmation and holy orders (ordination to the priesthood): these are sacraments that a person receives once off. It is also related to the terms such as the 'spiritual seal', an 'indelible mark', a 'character' and finally an 'ontological change'. The Catechism of the Catholic Church (CCC 1994) states that ordination 'confers an indelible spiritual character' which 'cannot be repeated or conferred temporarily' (CCC \#1583). 'The vocation and mission received on the day of ordination marks the person permanently' (CCC \#1583). Ordination is done once, as are Baptism and Confirmation. What is implied is that something (divine) was added to the being of the person when receiving the sacrament, and that something is an 'ontological change'. By virtue of the act of baptism, confirmation and ordination, the depths of the human person is altered by the Holy Spirit. Holy Orders place the ordained person in a certain standing in the community, not a better or more privileged place but a position from which one is called to be exclusive in the service of the People of God. According to the Catechism of the Catholic Church (1994), the baptised person and the ordained person share in the priesthood of Christ. The baptismal priesthood of all the faithful by virtue of baptism and confirmation is a share in the mission of Christ as priest, prophet and king. By these sacraments the faithful is consecrated to be a Holy Priesthood, a person set apart (CCC \#1546).

Ordination to ministerial priesthood is intimately connected with the celebration of other sacraments and in particular the Eucharist. Thomas Aquinas used the idea of transubstantiation, which refers to the 'ontological change' that takes place in the substance (the essence, or ontology) of the Bread and Wine at the Consecration while leaving outer appearance or any other non-essential property intact. Therefore, transubstantiation means that the Bread and Wine actually become the Body and Blood of Christ while still looking very much like regular bread and wine. This is theologically substantiated by the virtue of ordination by ordained priest who acts in persona Christi as stipulated in the Catechism of the Catholic Church (1994):

The ministerial or hierarchical priesthood of bishops and priests, and the common priesthood of all the faithful participate, 'each in its own proper way, in the one priesthood 
of Christ'. While being 'ordered one to another,' they differ essentially. ${ }^{8}$ In what sense? While the common priesthood of the faithful is exercised by the unfolding of baptismal gracea life of faith, hope, and charity, a life according to the Spirit--, the ministerial priesthood is at the service of the common priesthood. It is directed at the unfolding of the baptismal grace of all Christians. The ministerial priesthood is a means by which Christ unceasingly builds up and leads his Church. For this reason it is transmitted by its own sacrament, the sacrament of Holy Orders. (CCC \#1547)

The ordained priest acts in the person of Christ the Head...:

In the ecclesial service of the ordained minister, it is Christ himself who is present to his Church as Head of his Body, Shepherd of his flock, high priest of the redemptive sacrifice, Teacher of Truth. This is what the Church means by saying that the priest, by virtue of the sacrament of Holy Orders, acts in persona Christi Capitis. ${ }^{9}$ (CCC \#1548)

It is believed that this notion has been distorted by clericalism in the sense that the priest after ordination perceives himself, by virtue of ordination, different from ordinary human beings. This notion that the priest is a 'sacred person' has in many aspects contributed to exaggerated levels of unregulated power, which led to clerical abuse and exploitation. This is what Pope Francis is addressing all the time, the distortion of the priesthood by ordained clergy attributing unencumbered authority and status to themselves.

The Catechism of the Catholic Church (1994:390) sets out the effects of the sacrament of Holy Orders in the following manner:

The indelible character

This sacrament configures the recipient to Christ by a special grace of the Holy Spirit, so that he may serve as Christ's instrument for his Church. By ordination one is enabled to act as a representative of Christ, Head of the Church, in his triple office of priest, prophet, and king. (CCC \#1581)

As in the case of Baptism and Confirmation this share in Christ's office is granted once for all. The sacrament of Holy Orders, like the other two, confers an indelible spiritual character and cannot be repeated or conferred temporarily. (CCC \#1582)

It is true that someone validly ordained can, for grave reasons, be discharged from the obligations and functions linked to ordination, or can be forbidden to exercise them; but he cannot become a layman again in the strict sense, because the character imprinted by ordination is for ever. The vocation and mission received on the day of his ordination mark him permanently. (CCC \#1583)

The grace of baptism, confirmation and ordination is rooted in the awareness of specific ontological bond which unites the person to Christ: 'For as many of you as were baptised into Christ have put on Christ' (Gl 3:27). This, says Pope

8.Lumen Gentium $10 \$ 2$.

9.Lumen Gentium 10; 28; SC 33; CD 11; PO 2; 6.
Benedict XIV (2007:2)), is what is fulfilled in Baptism: We put on Christ. The 'ontological change' is spiritual in nature, in Catholic terms, a profound mystery. Concerning ordination, the bond between the Lord Jesus and the priest is an ontological and psychological bond as well as a sacramental and moral bond, which is the foundation and likewise the power for the 'life according to the spirit' and that 'radicalism of the Gospel' to which every priest is called today.

Unfortunately, a mistaken interpretation of this ontological change has been usurped by clericalism in the sense that this ontological change cannot be taken away from a person, irrespective of sinful deeds. After Vatican II, the hierarchy increasingly employed the term in persona Christi to describe the priest's role as acting in the person of Christ. This is no insignificant title, as to act in persona Christi means that ordained priests take on the persona of Christ by acting not only in Christ's authority but also as his icons (Bennett 2014:106). Many priests guilty of sexual abuse scandals and many other related offences took advantage of this theological interpretation that regardless of sinful deeds of an ordained person, by virtue of the grace of ordination, he still acts in the person of Christ. On 24 February 2019, at the closing Mass of Synod on sexual abuse, Pope Francis (2019) called priests involved in sexual abuse 'the tools of Satan'. Priesthood is of Christ, it is a gift. In baptism we 'put on Christ'. St Paul says in Galatians (2:20): 'It is no longer I who live, but Christ who lives in me'. For this reason priesthood, in its authentic form, should be separated from abusive clericalism.

\section{Agency measures necessary for the Catholic Church: Rooting out clericalism}

It is clear from above that clericalism, egotistical clericalism, in its current form needs to be eradicated.

The foundation of modern clericalism has its roots in the Counter Reformation and the Council of Trent. One of the notable accomplishments of the Council of Trent was to establish a regulated system and programme for the education of seminarians for the diocesan priesthood (O'Malley 2013:183-186). It is a known fact that the Jesuits exerted considerable influence on the training of priests and became legendary in their insistence for rigorously high academic and disciplinary standards. Audacious new initiatives were launched to establish and implement the Council of Trent's ${ }^{10}$ mandate for the higher standards of education in the preparation of priests (Session 23 of the Council of Trent, 1537).

Professional priest, as we know today, came as a result of the complete overhaul of the seminary system, initiated in France and then spread throughout Europe and other continents. The positive effect of providing Catholic priests with professional education was that it addressed

10.The Concilium Tridentinum was held from 1545 to 1563 in Trent, Northern Italy. It made major changes in the church at that time. Session 23 was devoted to the sacraments, which included clerical formation. 
the problem of traditional crass ignorance in the secular clergy. The negative side was that it further highlighted and intensified the social divide between the clergy and the laity. Clericalism, as a subculture of entitlement and privilege, took on another attraction for the ecclesiastical career-minded, who became priests (or clerics) just to obtain a qualification rather than to embrace the priesthood. While this clericalism was taking root through professionalism, there was another kind of priest present, namely the simple, heroic counter-cultural rustic Catholic pastor. These two different types of clergy developed side by side throughout the centuries, and an anti-clerical sentiment development largely in France. One of the most emblematic priestly figures that surfaced in this highly charged atmosphere of virulent anti-clericalism was Jean-Baptiste-Marie Vianney (08 May 1786-04 August 1859) (Trochu 1977:294). He was popularly known as 'the Cure of Ars', who eventually became the patron saint of pastoral priests, especially diocesan pastors. Similar to many of his fellow clergy, he was not well educated and found it hard to study as he was brought up with little formal schooling. His lack of formal education was compensated with his aggressive interventionist pastoral ministry. His moral rigourism provided reasons for his preoccupation with human sinfulness, hence he spent hours in the confessional. Originally, he was not a good confessor and his preachings constantly focused on the fear of eternal punishment and the consequent obsessive need for full confession and a firm intention never to sin again. These preoccupations were integral to Vianney's approach to pastoral ministry. Eventually, his arduous and subconscious manipulation of peoples' minds and souls was somewhat tempered by his exposure to the more accommodating, nuanced and compassionate moral praxis of Alphonsus de Ligouri, and he learned how to be a good confessor. The reading of $\mathrm{A}$ Study of the Theology of St. Alphonsus by Cardinal Gousset, tempered him somewhat in his ministry (Trochu 1977:294).

Vianney's writings provide valuable insights into the collective identity of the Catholic priest in the climate of the 18th century European socio-cultural flux and anticlericalism. Vianney, however, did not go out deliberately to combat professional clericalism; it was his manner and style of ministering that instinctively combatted clerical professionalism.

Contrariwise, to combat clericalism does not imply taking the anti-clerical route. To root out clericalism is to find virtuous path and balance, rather than choosing between two extremes. Addressing clericalism does not imply falling into a trap of anti-clericalism. Neither should the ordained person be put on a lofty pedestal, nor should we put them down in a degrading and demeaning position. Jesus has set the attitude of priesthood in Matthew 20:20-28:

You know that the rulers of the Gentiles lord it over them, and the great ones make their authority over them felt. But it shall not be so among you. Rather, whoever wishes to be great among you shall be your servant; whoever wishes to be first among you shall be your slave. Just so, the Son of Man did not come to be served, but to serve and to give his life as a ransom for many.

Peter echoed the words of Jesus in 1 Peter 5:3 when he wrote, ' $[d]$ o not lord it over those assigned to you, but be examples to the flock'.

\section{Sacerdotal clericalism}

The attitudes of sacerdotal clericalism stem from the complex Scholastic theology of the ordained priesthood that is often misunderstood by ordained priests themselves. The term 'sacerdotalism' is derived from the Latin sacerdos [priest], which literally means 'the one who offers sacrifices or make offerings'. Sacerdotium refers to the earthly hierarchy of priests and bishops, whose primary goal is the salvation of people and relate to the administration of sacraments, especially the Eucharist, baptism, confirmation and reconciliation. The theology of priestly ministry was reduced to the narrow scholastic category of sacrificial mediator, ex opera operato, which is connected to the theology of transubstantiation and spiritual power to absolve penitent from their sins in the sacrament of reconciliation. The Sacrament of Holy Orders has assumed de facto importance in Christian existence superior to that of baptism. The theological rationale of sacerdotal self-immolation took on a further theological overlay in the Latin rite with the mandatory imposition of celibacy on all ordained priests. The Second Vatican Council presents sacerdotalism as the teaching that:

[T]hrough the ministry of priests, the spiritual sacrifice of the faithful is made perfect in union with the sacrifice of Christ, the sole Mediator. Through the hands of the priests and in the name of the whole Church, the Lord's sacrifice is offered in the Eucharist in an unbloody and sacramental manner until $\mathrm{He}$ Himself returns. (CCC \#1545)

Thus, priests exercise the sacrificial function of Christ, the High priest who sacrificed his life for many, and the Eucharist testifies to this. The priestly ministry derives its mission, its meaning, its efficacy from Christ (CCC \#1557).

The preparation of priests with this complex theology in mind has made a large contribution towards modern sacerdotal clericalism. Pope Pius X's reforms evident in theological education and a standardised seminary regime had severe repercussions and produced generations of priests inoculated against what was accepted as a human normality. Growth towards a developed and rounded personality was impeded from the start. Reflections of this preparation established that profound psychological, emotional and spiritual inertia was the result. Blind obedience to authority and compliance with regulations were promoted as virtues. The development cost was enormous and that also at the expense of independent thinking, initiative and emotional maturity. Seminarians found themselves cut off from the reality checks such as the levelling effects of exposure to 
normal family life and socialising with women. Their forced isolation deprived them of practical knowledge of children and their stages of emotional and intellectual development. Institutional exemption from any significant domestic and financial realities greatly retarded the seminarian's moral development and sense of what most people would regard as normal human experience. ${ }^{11}$ The preparation of future clerics remained a matter of concern and received prime attention in the Second Vatican Council with the intention of bringing priestly preparation in line with the vision of church as articulated at the Council.

\section{Agency: Change the culture associated with the training of seminarians or priests}

Since the Second Vatican Council, the ground-breaking Post-Synodal Apostolic Exhortation Pastores Dabo Vobis made its appearance followed by numerous other excellent Synodal documents in recent times. As testified by the Congregation for the Clergy (2016) in the new Ratio Fundamentalis Institutionis Sacerdotalis of 2016:

\begin{abstract}
Pastores Dabo Vobis, in particular, explicitly sets out an integrated vision of the formation of future clerics, taking equal account of all four dimensions that involve the person of the seminarian: human, intellectual, spiritual and pastoral. Ministrorum Institutio seeks to show how the formation of seminarians finds a natural continuation in the ongoing formation of priests, so that the two form one single reality. For this reason, Benedict XVI decided to entrust responsibility for initial formation in the Seminary to the Congregation for the Clergy, which was already competent for the ongoing formation of clergy. He amended, therefore, the relevant articles of the Apostolic Constitution Pastor Bonus (28 June 1988), and transferred the Office for Seminaries to the Congregation for the Clergy. During his pontificate, Pope Francis has offered a rich Magisterium and a constant personal example regarding the ministry and life of priests, encouraging and supporting the work that has led to this present document. (pp. 1-2)
\end{abstract}

Despite these wonderful exhortations, it appears that clericalism still rears its ugly head as evident in the abuses that take place in the church and the debilitating hierarchical priestly leadership. The church continues to believe that hierarchical priestly leadership had been instituted by Christ and that this is attested by the Scriptures. The new approaches towards seminarian formation set out in Pastores Dabo Vobis does not seem to have made any significant breakthrough into the hardened comprehension and impact that clericalism has on priesthood. The formation of Roman Catholic priests that became highly scholarly during and after the Counter Reformation, and consequently elevated to the clerical and social status of priests, caused the Catholic laity to respect them more because of their pastoral and social mobility. This attitude still prevails, hence Pope Francis (2016) reminded the faithful on 19 March $2016^{12}$ as follows:

11.See http://www.bishop-accountability.org/resources/.

12.The 19 March letter of Pope Francis to Cardinal Marc Ouellet of the Pontifical Commission for Latin America. He communicated strong comments on the importance of laity, and on the dangers of clericalism. This is now available in English on the Vatican website.
Lay people are part of the faithful Holy People of God and thus are the protagonists of the Church and of the world; we [priests] are called to serve them, not to be served by them. (n.p.)

Priestly formation has to combat the development of elevated statuses. The concept servus servorum Dei [servant of the servants of God] is receiving renewed attention in the exhortation of priestly formation in Pastores Dabo Vobis, the Post-Synodal Apostolic Exhortation of John Paul 1l, which means 'I will give you shepherds'. This idea of a priest being the servant of the servants of God has been prominent since the time of St. Gregory, the Great, 540 to 604 CE. Popes adhered to the title and task of the clergy as servus servorum Dei [servant of the servants of God]. The clergy are not masters but servants in the form of helpers. The priest, by virtue of ordination and Holy Orders, was and is regarded as an icon of Jesus Christ, who sacrificed his life for the People of God, the faithful. The sense of service has to sustain the Catholic theology of priesthood: "The call to service in the Church comes from God and is acknowledged and validated by the church' and he is 'consecrated for the task' (Stravinskas 1997:75-76). This remains a challenge in today's society where money and secular status are accentuated.

\section{Agency: Promote Catholic priesthood as servus servorum Dei}

There is no shortage of good documentation in the Catholic Church concerning the training of seminarians, but the training of the priesthood has to be separated from the scourge of clericalism (Pope Francis 2016). The Congregation for the Clergy brought out several excellent documents on the training and formation of catholic priests, but the immoral idea of clericalism that sneaks in has to be constantly investigated, monitored and addressed. Diminishing priesthood is not the answer, but what is definitely important is the change in the culture that has been associated with Catholic priesthood, the training of seminarians, to encourage a greater share of lay involvement and to open entrance of women to clerical ordination. This implies reversion to priesthood according to the teachings of Christ.

It is a challenge to train priests in the order of servus servorum Dei without neglecting scholarly and professional teachings. The challenge is to strike a healthy balance and instil in priests the right disposition to be of service as indicated by the Post-Synodal Apostolic Exhortation of John Paul 1l, entitled Pastores Dabo Vobis. The Apostolic Exhortation sets out a priestly formation based on the integrated development of spiritual, psychological, emotional and intellectual growth with the idea of producing Shepherds, as was demonstrated by Christ. This integrated formation is a response to the call to holiness and the configuration to Christ as Shepherd steeped in pastoral charity. The emphasis is largely on pastoral service and the personal formation of priest, human development being the foundation of priestly formation, strengthened by spiritual formation so as to be in union with God and in search of Christ. Intellectual formation leads to an understanding of faith, and pastoral formation leads to 
communion with the charity of Christ, the Good Shepherd. The environment has to be community-based, and that the seminary transforms into an educational-formational community that comprises professors in theology, philosophy, spirituality, moral theology and pastoral theology and the human formation that includes sexual and moral development that is in touch with the church and society. The focus is to create a formation that is integrated and to produce healthy and holistic pastoral priests that work closely with lay ministers. In Evangelii Gaudium 2013 (The Joy of the Gospel), Pope Francis spoke of cultural challenges (pp. 61-67) such as secularism, individualism and globalisation that form the context of priestly ministry (pp. 68-70) but encourages human development that equips priests with the fluency to link the message of a biblical text to a human situation...' (p. 154). Schuth (2016:32) writes on seminary formation: 'Clerical leadership is singular in its power to shape the life of the Christian community and to engage the wisdom and commitment of lay ecclesial ministers and parishioners'.

\section{Agency: Lift the exclusion of women ordination towards full participation in the life and ministry of the church}

The exclusion of women in all spheres of life, and in particular in the Catholic Church, is a longstanding practice. Theological debates over the admittance of women to ordained ministry are closed, and scripture texts which are culture-bound are used to bolt such a door. 1 Timothy 2 is such an exploited text among many others:

12 And I do not permit a woman to teach or to have authority over a man, but to be in silence. 13 For Adam was formed first, then Eve. 14 And Adam was not deceived, but the woman being deceived, fell into transgression. (vv. 12-14)

This cultural prejudice has clouded the interpretations of theologians as well as their sense of judgement for many centuries. This text, says Wijngaards (2001:8) (a scripture scholar who focused his life's work on fighting for women ordination), was written in a context of a Gnostic threat to which women were considered especially vulnerable. This, in Wijngaards (2001:8) view, is not an inspired scripture but a cultural interpretation imposed on Scripture. Nine such scripture passages had been used to exclude women from ordination. Cultural prejudice rather than God's will is therefore responsible for women's exclusion from ordained ministry. Currently, the Roman Catholic Church only ordains men as deacons and priests. According to the teaching on ordination, as it appears in the Code of Canon Law, the Catechism of the Catholic Church and the Apostolic letter on Ordinatio Sacerdotalis', only a baptised man (vir in Latin) can validly receive the sacrament of Holy Orders.

The magisterium claims that it has no authority to confer ordination on women. Their teaching is that this judgement is to be adhered to by all the Church's faithful. When the Second Vatican Council dealt with the church, they struggled between two different types of models of the church. The one being the clerical and hierarchical model operative since medieval times, and the second model that perceives the church as the People of God. The People of God model stresses communion, co-responsibility and Christian values such as grace and love. This model promotes maximum participation of the laity, men and women. This model lends itself to the full cooperation of the faithful, but stops short before the ordination of women. The authorities in Rome could not free themselves from the hierarchical model, even though Second Vatical Council promoted the concept of People of God model evident in the document Lumen Gentium (Chapter two).

Several women who genuinely feel or called to the priesthood continue to suffer the pain of exclusion, and started to search for a different model of church such as a more communitarian model of ministry. Many were of the opinion that even though they are called to the priesthood, they could in conscience not accept ordination from a church that promotes clericalism, imposes celibacy and hierarchical priesthood (Wijngaards 2001:29). However, in 2002, several Roman Catholic women took it upon themselves to be ordained as deacons, priests and bishops, and they claimed that their ordinations were valid because these were administered by a validly ordained Catholic male bishop Romulo Antonio Braschi, but who left the ministry in 1975. In reaction, on 02 December 2002, the Congregation for the Doctrine of the Faith issued the Decree on the Attempted Ordination of Some Catholic Women. This was issued by the Sovereign Pontiff John Paul II, and signed by the Prefect of the Congregation for the Doctrine of the Faith, Cardinal Ratzinger (2002). The decree states (Ratzinger 2002):

On June 29, 2002, Romulo Antonio Braschi, founder of a schismatic community, attempted to ordain the following Catholic women to the priesthood:Christine Mayr-Lumetzberger, Adelinde Roitinger, Gisela Forster, Iris Müller, Ida Raming, Pia Brunner and Dagmar Braun Celeste, who on that occasion identified herself as Angela White.

Citing the previous interventions of the Bishop of Linz and of the Austrian Episcopal Conference, the Congregation for the Doctrine of the Faith published a Statement on July 10, 2002, warning the above-mentioned persons that they would be punished with excommunication if by July 22, 2002, they had not acknowledged the nullity of their 'ordination' and asked forgiveness for the scandal caused to the faithful. As they gave no indication of amendment, this congregation punished the aforementioned persons with excommunication, reserved to the Apostolic See, in the Decree dated Aug. 5, 2002, expressing the hope that they might be moved to conversion. The decree also confirmed that the 'ordaining' bishop was already excommunicated insofar as he is a schismatic. (n.p.)

Pope John Paul 11 (1992) reiterated the church's stance as set out in Ordinatio Sacerdotalis, 4: 'That the church has no authority whatsoever to confer priestly ordination on women'. He also endorsed the Code of Canon Law (Canons $750 \S 2 ; 1372$, n. 1): 'That those who are in denial of this doctrine are rightly considered the denial of a truth that pertains to the Catholic faith and therefore deserves a 
just penalty'. These women and others who were ordained subsequently were excommunicated, and hence further excluded. The ordained women wrote letters to the Congregation of the Doctrine of the Faith as stated in the decree (Canon 1331§1):

They subsequently published letters and granted interviews in which they expressed their conviction regarding the validity of the 'ordination' they received, calling for a change of the definitive doctrine according to which ordination to the priesthood is reserved to males and reaffirming that they celebrate 'Mass' and other 'sacraments' for small groups. In a letter dated Aug. 14, 2002, they asked that the decree of excommunication be revoked and then, on Sept. 27, 2002, with reference to Canons 1732-1739 of the Code of Canon Law, they made recourse against the decree. On Oct. 21, 2002, they were informed that their request would be submitted to the competent authority. (p. 236)

The excommunication was substantiated in the following manner in the decree (Canon 1331§1):

There is first of all, the issue of schism: The above-mentioned women were 'ordained' by a schismatic bishop and - even though not formally adhering to his schism - thereby made themselves accomplices in schism. (p. 236)

The act of ordination was regarded by the hierarchical church authorities as open and divisive disobedience to the Roman Pontiff and diocesan Bishops. The outcome was as follows (cf. Canon 1331§1):

The above-mentioned members of the Congregation of the Doctrine of the Faith, therefore, confirm the Decree of excommunication issued on Aug. 5, 2002, specifying once again that the attempted priestly ordination of the aforementioned women is null and invalid (cf. Canon 1024) and therefore all those actions proper to the order of priesthood performed by them are also null and invalid (cf. Canons 124; 841). In consequence of the excommunication, they are forbidden to celebrate sacraments or sacramentals, to receive the sacraments and to exercise any function in an ecclesiastical office, ministry or assignment. (n.p.)

Women are continued to be ordained since 2002 by women bishops, but this excommunication on them was reiterated in 2008 by an excommunication order on 29 May 2008. This was published in the Vatican Newspaper L'Osservatore Romano, a decree signed by Cardinal William Levada, stating that women 'priests' and the bishops who ordain them (men or women) would be automatically excommunicated latae sententiae, a term used in the Canon Law, which means 'already sentenced', already found guilty by virtue of ordination. The decree called for the conversion of the women and 'so return to the unity of faith and to communion with the Church, a communion broken by their action' (No. 5 of the decree).

This doctrine and sentiment of exclusion were confirmed by Pope Francis in November 2016 when he said 'that door is closed' concerning the priestly ordination of women. He said he affirms the teachings of his immediate predecessors, namely Pope John Paul 11 (1992) and Pope Benedict VI (Pullella 2012), and these won't be tampered by him. He also holds on to the Petrine dimension, which derives from the Apostle Peter, and the Apostolic College, which is the pastoral activity of bishops. He maintains that the Church is depicted as the Bride of Christ, hence women cannot be priests because they cannot be bridegrooms. He did, however, authorised a commission on 20 June 2018 to see whether women again could be made deaconesses. Whether this will be accompanied with ordination remains to be seen. For now, however, ordination of women is perceived as doctrinally not permissible, and Pope Francis in an interview with Reuters on 20 June 2018 said: ordination is not a 'capricious thing'. So the doors to ordain women remained close. In the meantime, Catholic women who were ordained remained excommunicated and in schism with the church.

The ordained women established an Association of Roman Catholic Women Priests (ARCWP). They regard their movement as prophetic and describe themselves as educated, experienced and seasoned Catholics whose aim is to restore equality and inclusiveness in the church. There are approximately 205 ordained women in the world and the majority are in the USA. They regard themselves as validly ordained, although they are excommunicated because of gender by the hierarchy of the Roman Catholic Church. They do vest in clerical wear, but deviate in some practices so as to break with hierarchical practices. These ordained women do not have churches, parishes or dioceses, but function pastorally and sacramentally. They celebrate the Eucharist and all other sacraments in 'house churches'. They do hospital and hospice chaplaincy, prison ministry, anoint the sick and elderly, administer weddings and funerals, minister the homeless and offer spiritual directions and retreats. They are not accountable to the local hierarchy and function in isolation.

\section{Agency: Separating priesthood from negative clericalism}

While the ordination of women is not on the cards in the Catholic Church, what could be worked on is to change and restructure the image of the priesthood and to separate it from damaging clericalism. Negative clericalism has done Catholic priesthood a great deal of harm. This article advocates positive change and proposes that the formation of priests be vigilant against clericalism and to deliver men of prayer, who are steeped in the identity of Christ, the Priest. The priestly call, says Rossetti (2005:82), is a call to passionate living and loving, and while 'celibacy is excoriated in our culture and blamed for many of the ills within the church', celibacy is not a cause of deviancy (2005:84). Sexual abuse and sexual deviant behaviour are longstanding problems in an individual and this predates entrance into seminary formation. Rossetti (2005) claims that there are no indications that the incidences of child sexual abuse are higher in the priesthood than in any other male professions. ${ }^{13}$ There are no

13 The study: "The nature and scope of the problem of sexul abuse of minor..... Catholic Priests and Deacons in the US' conducted by the John Jay College of Criminal Justice for the US Conference of Catholic Bishops, the outcome is that the Criminal Justice for the US Conference of Catholic Bishops, the outcome is that the
committee found that about $4 \%$ of Catholic priests had allegations of child sexual abuse from 1950 to 2002 . 
convincing evidences that celibacy causes child sexual abuse or exacerbates its underlying deviant sexual tendencies. The problem is societal, and much deeper. This was borne out by the Pew Research Centre on 11 June 2019 that sexual abuse rates almost equal among all religious denominations.

There is no doubt that clericalism has to give way to a more gender-integrated church. Recent gender studies have made it clear that gender is much broader than masculinity and femininity. Clericalism has to make way for the recognition of gender as well as sexual diversity and not to perceive these realities as anomalies. Deeper studies and research into human nature with compassionate assimilations of differences that priesthood, rather than clericalism, have to be dealt with in a pastoral context. Since clericalism often displays outright rejection and denunciation of uncomfortable moral issues, what is required is the renewal of priesthood, renewal of church leadership and to face difficult questions and issues with spiritual courage that recognise the sacredness of priesthood and the frailty of humanity. Leadership needs to demonstrate openness, accountability and transparency.

\section{Conclusion}

Priority attention has to be given to purging the church of clericalism, which is often expressed in other ways, such as the discriminatory scapegoating of gay persons and the marginalisation of free thinkers and women clerics. Discrediting the personal authority of the pope is not the best and enlightened option. What ought to be discredited is the centralisation of authority and control so as to allow much more informed local diocesan initiatives and the laity participation, whereby crises, such as sexual abuse scandals, could be addressed and solved more speedily and liberally with no need to go to the top hierarchy for solutions. To wait for centralised, hierarchical structures to deal with urgent issues is not desirable, as speedy accountability is needed to address issues that hurt the church in its entirety. The de-clericalisation of the Catholic Church has become a moral doctrinal agency, which could only increase the ethical accountability of hierarchical leadership.

\section{Acknowledgements}

\section{Competing interests}

The author declares that she has no financial or personal relationships which may have inappropriately influenced her in writing this article.

\section{Author's contributions}

J.L. is the sole contributor to this research article.

\section{Ethical considerations}

This article followed all ethical standards for a research without direct contact with human or animal subjects.

\section{Funding information}

This research received no specific grant from any funding agency in the public, commercial, or not-for-profit sectors.

\section{Data availability statement}

Data sharing is not applicable to this article as no new data were created or analysed in this study.

\section{Disclaimer}

The views and opinions expressed in this article are those of the author and do not necessarily reflect the official policy or position of any affiliated agency of the author.

\section{References}

Abraham, G., 2019, 'Sex scandals divide the Catholic Church', Mail and Guardian, 08 March 2019, viewed 24 October 2019, from https://mg.co.za/article/2019-0308-00-sex-scandals-divide-the-catholic-church.

Aquinas, T., 1981, The Summa theologicae (1a Q2), 'Whether the existence of God is self-evident', Thomas More Publishing, s.l.

Austin, F., 1996, Vatican Council 11, vol. 1, the post-concilliar documents, new revised edn., Dominican Publications, Dublin.

Bennett, K.R., 2014, 'Divided anthropology: An ontological look at the Vatican's rejection of women's ordination', Andrews University Seminary Studies 52(1), 101-115, Andrews University Press.

Bergenke, T., 2006, 'St Constantine the great: Influential figure in the history of the church', The Journal of the Chicago Pastoral School 1(2006), viewed 22 October 2019, from www.bishop-accountability.org/news2015/03.../2015_04_03_OMG_ Clericalism.htm.

Catechism of the Catholic Church, 1994, Pauline Publications of Africa, Mambo Press, Nairobi.

Congregation for the Clergy, 2016, The gift of the priestly vocation: Ratio fundamentalis institutions Sacerdotalis, L'Osservatore Romans, Vatican City, Rome.

Deane, S.W., 1962, Anselm's basic writings, transl. S.W. Deane, 2nd edn., Open Court Publishing, La Salle, IL.

Flannery, A. (ed.), 1998, Vatican Council II Volume 1, The Councillor and Post Councillor Documents, New Revised edn., Domincan Publications, Dublin.

Glatz, C., 2014, 'Pope: Bishops must be servants, not vain careerists after power honor', National Catholic Reporter, Catholic News Service, 05 November, viewed 22 October 2019, from https://www.ncronline.org/blogs/francis-chronicles.

John Paull II. 1994. Apostolic Letter Ordinatio Sacerdotails Of John Paul II to the Bishops of the Catholic Church on Reserving Priestly Ordination to Men Alone. The Solemnity of Pentecost, 22 May, Vatican, Rome.

John Paul II 1992. Post-Synodal Apostolic Exhortation: Pastores Dabo Vobis (To the bishops, clergy and faithful on the formation of priests in the circumstances of the present day), Liberia Editrice Vaticana, St. Paul Books and Media, Boston, MA.

Kelly, M., 2014, Michael Kelly SJ. Next item on the Catholic reform agenda, viewed 22 October 2019, from https://johnmenadue.com/michael-kelly-sj-next-item-onthe-catholic-reform-agenda.

Liberia Editrice Vaticana, 1983, The Code of Canon Law, transl. Canon Law Society Trust, Collins Liturgical Publications, London.

Neuhaus, R.J., 2008, 'The public square: A continuing survey of religion, culture and public life', First Things: A Monthly Journal of Religion and Public Life (179), 59.

O'Malley, J.W., 2013, Trent: What happened at the council, Harvard University Press, Harvard, MA.

Owles, J.R., 2014, The Didache: The teaching of the twelve apostles (Translation) Joseph Owles via Create Space Independent Publishing Platform, Scotts Valley, CA.

Pope Benedict XIV, 2007, 'Holy Chrism Mass: In Persona Christi', L'Osservatore Romano, Weekly Edition in English, 13 April 2007, p. 2.

Pope Francis, 2013, Apostolic Exhortation Evangelii Gaudium, Vatican City Press, Vatican, Rome.

Pope Francis, 2016, Letter of Pope Francis to Cardinal Marc Ouellet of the Pontifical Commission for Latin America, viewed, n.d., from http://w2.vatican.va/content/ francesco/en/letters/2016/documents/papa-francesco_20160319_pont-commamerica-latina.html.

Pope Francis, 2018a, Apostolic Exhortation Gaudete Et Exsultate: On the call to Holiness in today's world, Libreria Editrice Vaticana, Rome.

Pope Francis, 2018b, Letter of His Holiness Pope Francis to the people of God, 20 August 2018, Vatican City Press, Vatican, Rome.

Pope John Paul II, 1992, Post Synodal Apostolic Exhoration of John Paul II. I will give you Shepherds, Pastores Dabo Vobis, St Paul's Books and Media, Boston, MA.

Pope John Paul II, 1994, Apostolic Letter Ordinatio Sacerdotalis Of John Paul II To The Bishops Of The Catholic Church On Reserving Priestly Ordination To Men Alone, viewed n.d., from http://w2.vatican.va/content/john-paul-ii/en/apost letters/1994/documents/hf_jp-ii_apl_19940522_ordinatio-sacerdotalis.html.

Pullella, P., 2012, 'Pope reaffirms ban on women priests, assails disobedience', Reuters, viewed n.d., from https://www.reuters.com/article/us-pope/popereaffirms-ban-on-women-priests-assails-disobedience-idUSBRE83500U201 20406 
Ratzinger, J., 2002, Congregation for the doctrine of the faith: Decree on the attempted ordination of some Catholic women, from the Offices of the attempted ordination of some Catholic women, from the Offices of the
Congregation for the Doctrine of the Faith, Rome, 21 Dec. 2002, Vatican City Congregation for the
Press, Vatican, Rome.

Richardson, A. \& Bowden, J. (eds.), 2002, The Westminster Dictionary of Christian Theology, Westminster Press, Philadelphia, PA.

Rossetti, S.J., 2005, The joy of priesthood, Ave Maria Press, Notre Dame, IN.

Sacred Congregation for the Doctrine of the Faith, 1983, Sacerdotium Ministeriale: Letter on Certain Questions Concerning the Minister of the Eucharist, Veritas Publications, Dublin.

Schuth, K., 2016, Seminary formation: Recent history - Current circumstances - New directions, Litrugical Press, Collegeville, MN.

Settanni, J.A., 2016, Theology and ontology: Roman Catholic reflections on ontologica theology, viewed 08 September 2016, from https://callthepatriot.wordpress. com/theology-and-ontology-roman-catholic-reflection.
Shaw, R., 1993, To hunt, to shoot, to entertain: Clericalism and Catholic laity, Ignatius Press, San Francisco, CA.

Shaw, R., 2008, Nothing to hide: Secrecy, communication, and communion in the Catholic Church, St Ignatius Press, San Francisco, CA.

Stravinskas, P.M.J.,1997, Understanding the sacraments: A guide for prayer and study, Ignatian Press, San Francisco, CA.

Trigilio, R., 2015, It is not what a man wears, but how he acts and treats others that tells who he really is, Clericalism: OMG!, viewed April 03 2015, from https://www. ohmygodjournal.org/?page_id=434.

Trochu, A.F., 1977, The Curé d'Ars, TAN books, Charlotte, NC.

Vogt, A., 2019, 'Pope compares child sex abuse to human sacrifice as he promises to combat "with the wrath of God"', The Telegraph, viewed n.d., from https://www. telegraph.co.uk/news/2019/02/24/pope-vows-fight-sex-abuse-church-wrath-god.

Wijngaards, J., 2001, The ordination of women in the Catholic Church: Unmasking a cuckoo's egg tradition, Darton, Longman and Todd, London. 